\title{
Crystal Structure of [1-(1H-Benzoimidazol-2-yl)-ethanone thiosemicarbazone $]_{2} \mathrm{Nickel},\left[\mathrm{C}_{20} \mathrm{H}_{22} \mathrm{~N}_{10} \mathrm{~S}_{2} \mathrm{Ni}\right]$
}

\author{
Musa SARI, ${ }^{* 1 \dagger}$ Mehmet Poyraz, ${ }^{* 2}$ Şeref DemirayaK, ${ }^{* 3}$ and Orhan BüYÜKGÜNGöR*4 \\ *1 Department of Physics Education, Gazi Education Faculty, Gazi University, \\ Besevler 06500, Ankara, Turkey \\ *2 Department of Chemistry, Science and Arts Faculty, Afyon Kocatepe University, Afyon, Turkey \\ *3 Department of Pharmaceutical Chemistry, Pharmacy Faculty, Anadolu University, Eskisehir, Turkey \\ *4 Department of Physics, Ondokuzmayxıs University, TR-55139, Samsun, Turkey
}

\begin{abstract}
The title compound, $\left[\mathrm{C}_{20} \mathrm{H}_{22} \mathrm{~N}_{10} \mathrm{~S}_{2} \mathrm{Ni}\right]$, crystallizes in the triclinic space group $P \overline{1}$ with cell parameters $a=10.9319(9) \AA$, $b$ $=12.0083(9) \AA, c=13.4978(11) \AA, \alpha=87.057(7)^{\circ}, \beta=85.841(7)^{\circ}, \gamma=63.820(6)^{\circ}, V=1585.6(2) \AA^{3}, Z=2$. The structure was refined to a final $R$ value of 0.0498 for 4798 reflections $[I>2 \sigma(I)]$. The nickel atom is in a regular octahedral environment by four nitrogen atoms and two sulfur atoms.
\end{abstract}

(Received February 1, 2005; Accepted August 15, 2005; Published on web December 2, 2005)

Thiosemicarbazones and their metal complexes have received considerable attention because of their biological properties. They also contain $\mathrm{N}=\mathrm{C}-\mathrm{C}=\mathrm{N}$ structure unit, which forms a strong

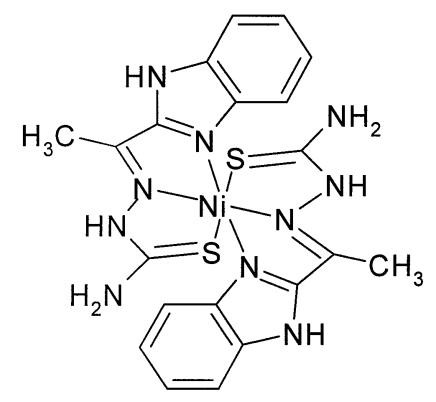

Fig. 1 Chemical diagram of the title compound.

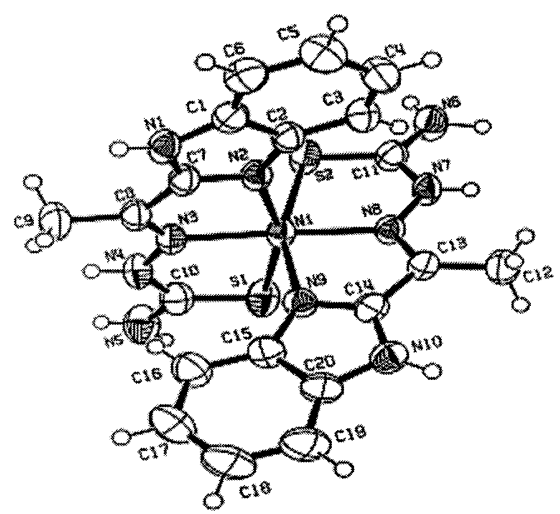

Fig. 2 Molecular structure of the title compound with the atom numbering scheme. The thermal ellipsoids are drawn at the $50 \%$ probability level.

$\doteqdot$ To whom correspondence should be addressed.

E-mail address: msari@gazi.edu.tr chelate ring giving possible electron delocalization associated with extended conjugation that may effect the nature of the formed complex. The biological activity of these compounds was attributed to their interaction with enzymes, such as ribonucleotide reductases, the RNA dependent DNA polymerase, the formation of oxygen active species, and the reaction with cell thiols. ${ }^{2-5}$ The title complex is shown in Fig. 1 and Fig. 2.

Table 1 Crystal and experimental data

\footnotetext{
Formula: $\mathrm{C}_{20} \mathrm{H}_{22} \mathrm{~N}_{10} \mathrm{~S}_{2} \mathrm{Ni}$

Formula weight $=525.29$

Crystal system: triclinic

Space group: $P \overline{1} \quad Z=2$

$a=10.9319(9) \AA \quad \alpha=87.057(7)^{\circ}$

$b=12.0083(9) \AA \quad \beta=85.841(7)^{\circ}$

$c=13.4978(11) \AA \quad \gamma=63.820(6)^{\circ}$

$V=1585.6(2) \AA^{3}$

$D_{\mathrm{x}}=1.100 \mathrm{~g} / \mathrm{cm}^{3}$

$\mu\left(\right.$ Mo $\left.K_{\alpha}\right)=0.766 \mathrm{~mm}^{-1}$

$T=293 \mathrm{~K}$

Crystal color: prism, dark red

$\lambda\left(\right.$ Mo $\left.K_{\alpha}\right)=0.71073 \AA$

$R=0.0498 w R=0.1323$

No. of reflections measured $=6949$

No. of reflections used $=4798[I>2 \sigma(I)]$

No. of parameters $=306$

Goodness-of-fit: 0.974

$(\Delta / \sigma)_{\max }=0.011$

$(\Delta \rho)_{\max }=0.864 \mathrm{e}^{-3}$

$(\Delta \rho)_{\min }=-0.608 \mathrm{e}^{-3}$

$2 \theta_{\max }=54.26^{\circ}$

Measurements: Stoe IPDS-2 diffractometer

Program system: X-AREA software

Structure determination: SHELXS-97

Refinement: SHELXL-97

Hydrogen atoms: geometrically located

Refinement: full-matrix least-squares on $F^{2}$

Deposit number: CCDC 270038
} 
Table 2 Final atomic coordinates and equivalent anisotropic thermal parameters for non-hydrogen

\begin{tabular}{|c|c|c|c|c|}
\hline Atom & $x$ & $y$ & $z$ & $U_{\mathrm{eq}}\left(\AA^{2}\right)$ \\
\hline $\mathrm{Ni}$ & $0.75092(5)$ & $0.59053(4$ & $0.20729(3)$ & $0.0392(6)$ \\
\hline N1 & $0.5391(3)$ & $0.4037(3)$ & $0.1254(2)$ & $0.0392(14)$ \\
\hline N2 & $0.5981(3)$ & $0.5541(2)$ & $0.15385(19)$ & $0.0442(7)$ \\
\hline N3 & $0.8516(3)$ & $0.4030(2)$ & $0.1838(2)$ & $0.0402(6)$ \\
\hline N4 & $0.9857(3)$ & $0.3392(3)$ & $0.2008(2)$ & $0.0419(6)$ \\
\hline N5 & $1.1839(4)$ & $0.3344(4)$ & $0.2440(3)$ & $0.0503(7)$ \\
\hline N6 & $0.6687(4)$ & $0.9312(3)$ & $0.0268(3)$ & $0.0678(10)$ \\
\hline N7 & $0.6128(3)$ & $0.8644(3)$ & $0.1742(2)$ & $0.0631(10)$ \\
\hline N8 & $0.6306(3)$ & $0.7724(2)$ & $0.24263(19)$ & $0.0461(7)$ \\
\hline N9 & $0.6817(3)$ & $0.5750(2)$ & $0.35370(19)$ & $0.0414(6)$ \\
\hline N10 & $0.5607(3)$ & $0.6813(3)$ & $0.4855(2)$ & $0.0484(7)$ \\
\hline S1 & $0.97316(10$ & $0.55323(9$ & $0.26056(9)$ & $0.0578(3)$ \\
\hline $\mathrm{S} 2$ & $0.78618(11$ & $0.68705(8$ & $0.05260(7)$ & $0.0546(3)$ \\
\hline $\mathrm{Cl}$ & $0.4225(4)$ & $0.5135(3)$ & $0.1167(2)$ & $0.0422(7)$ \\
\hline $\mathrm{C} 2$ & $0.4620(4)$ & $0.6076(3)$ & $0.1344(2)$ & $0.0412(7)$ \\
\hline $\mathrm{C} 3$ & $0.3656(4)$ & $0.7321(3)$ & $0.1301(3)$ & $0.0485(8)$ \\
\hline $\mathrm{C} 4$ & $0.2360(4)$ & $0.7567(4)$ & $0.1104(3)$ & $0.0566(9)$ \\
\hline $\mathrm{C} 5$ & $0.1981(4)$ & $0.6613(4)$ & $0.0937(3)$ & $0.0580(9)$ \\
\hline C6 & $0.2911(4)$ & $0.5391(4)$ & $0.0969(3)$ & $0.0520(9)$ \\
\hline $\mathrm{C} 7$ & $0.6399(4)$ & $0.4322(3)$ & $0.1478(2)$ & $0.0423(7)$ \\
\hline $\mathrm{C} 8$ & $0.7811(4)$ & $0.3462(3)$ & $0.1626(2)$ & $0.0439(7)$ \\
\hline $\mathrm{C} 9$ & $0.8318(5)$ & $0.2094(3)$ & $0.1557(3)$ & $0.0602(10)$ \\
\hline $\mathrm{C} 10$ & $1.0522(4)$ & $0.4018(3)$ & $0.2339(3)$ & $0.0515(8)$ \\
\hline $\mathrm{C} 11$ & $0.6852(4)$ & $0.8347(3)$ & $0.0852(2)$ & $0.0460(8)$ \\
\hline $\mathrm{C} 12$ & $0.4672(4)$ & $0.9215(3)$ & $0.3635(3)$ & $0.0585(10)$ \\
\hline $\mathrm{C} 13$ & $0.5647(3)$ & $0.7978(3)$ & $0.3281(2)$ & $0.0404(7)$ \\
\hline $\mathrm{C} 14$ & $0.5999(3)$ & $0.6855(3)$ & $0.3894(2)$ & $0.0407(7)$ \\
\hline $\mathrm{C} 15$ & $0.6975(4)$ & $0.4924(3)$ & $0.4323(3)$ & $0.0461(8)$ \\
\hline $\mathrm{C} 16$ & $0.7701(4)$ & $0.3641(4)$ & $0.4380(3)$ & $0.0566(9)$ \\
\hline $\mathrm{C} 17$ & $0.7664(5)$ & $0.3058(4)$ & $0.5275(3)$ & $0.0678(11)$ \\
\hline $\mathrm{C} 18$ & $0.6923(5)$ & $0.3730(5)$ & $0.6101(3)$ & $0.0711(12)$ \\
\hline C19 & $0.6172(5)$ & $0.4994(4)$ & $0.6060(3)$ & $0.0633(11)$ \\
\hline $\mathrm{C} 20$ & $0.6219(4)$ & $0.5577(3)$ & $0.5157(3)$ & $0.0487(8)$ \\
\hline
\end{tabular}

$U_{\mathrm{eq}}=(1 / 3) \sum_{i} \sum_{j} U_{i j} a_{i}^{*} a_{j}^{*}\left(\boldsymbol{a}_{i} \cdot \boldsymbol{a}_{j}\right)$

The crystalline ligand $(0.125 \mathrm{~g}, 0.538 \mathrm{mmol})$ was dissolved in 40 $\mathrm{ml}$ ethanol, $\mathrm{NiCl}_{2}(0.0349 \mathrm{~g}, 0.269 \mathrm{mmol})$ was dissolved in wet ethanol. The $\mathrm{NiCl}_{2}$ solution was added to the ligand solution. The mixture was refluxed on a hot plate at $60-70^{\circ} \mathrm{C}$ for $6 \mathrm{~h}$. It was left for crystallization. The structure was solved by direct methods, and refined on $F^{2}$ by full-matrix least-squares procedures. The non-hydrogen atoms were refined anisotropically, and all of the hydrogens were fixed as a riding model over their parent atoms with $U_{\text {iso }}(H)=1.3 U_{\mathrm{eq}}(\mathrm{C})$. The average $\mathrm{Ni}-\mathrm{N}$ and $\mathrm{Ni}-\mathrm{S}$ bond lengths are [2.070(10) and $2.425(4) \AA]$, respectively. The nickel ion is linked to the azomethinic nitrogen $\mathrm{N} 3$ and the thioamide sulfur $\mathrm{S} 1$ atoms. The bond distances are 2.061(9) $\mathrm{\AA}$ and 2.425(4) $\mathrm{A}$, respectively. The azomethinic nitrogens [N3 and N8] are placed in a trans position. The trans angle involving the azomethinic nitrogens, $171.95(12)^{\circ}$, most closely approaches $180^{\circ}$.

The coordination about the nickel ion is not completely regular; the bond angles at the $\mathrm{Ni}(\mathrm{II})$ atom range from [78.3(4) to $\left.105.6(3)^{\circ}\right]$. The best plane is defined by atoms S1, C7, C8, C10,

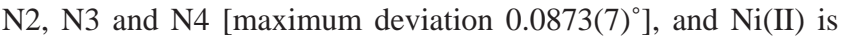
located only $0.003(4)^{\circ}$ from this plane. The planes, Ni, N8, N9,
Table 3 Selected bond distances $(\AA)$ and angles $\left(^{\circ}\right)$

\begin{tabular}{llll}
\hline N2-Ni & $2.091(10)$ & N9-Ni & $2.086(10)$ \\
N3-Ni & $2.061(9)$ & N3-N4 & $1.352(4)$ \\
S1-Ni & $2.425(4)$ & N7-N8 & $1.358(4)$ \\
S2-Ni & $2.425(4)$ & C10-S1 & $1.683(14)$ \\
N8-Ni & $2.041(10)$ & C11-S2 & $1.682(14)$ \\
& & & \\
S1-Ni-S2 & $91.52(15)$ & N2-Ni-N9 & $90.6(4)$ \\
N3-Ni-S1 & $81.2(3)$ & N8-Ni-S2 & $81.51(8)$ \\
N9-Ni-S1 & $91.2(3)$ & N3-Ni-S2 & $105.11(8)$ \\
N8-Ni-N2 & $97.3(4)$ & N2-Ni-S2 & $93.82(8)$ \\
N3-Ni-N2 & $78.3(4)$ & N8-Ni-N9 & $78.4(4)$ \\
N8-Ni-S1 & $103.29(8)$ & N3-Ni-N9 & $94.8(4)$ \\
& & & \\
C8-N3-Ni-N8 & $45.0(9)$ & C8-N3-Ni-S2 & $-99.7(2)$ \\
C10-S1-Ni-N2 & $3.5(3)$ & C10-S1-Ni-S2 & $-102.04(14)$ \\
N6-C11-S2-Ni & $178.0(3)$ & S1-Ni-S2-C11 & $-103.61(14)$ \\
& & &
\end{tabular}

C13, C14 and Ni, S1, N3, N4, C10 have mean plane deviations of 0.023(4) and -0.013(5), respectively. These two coordination planes are at an angle of $88.8(3)^{\circ}$ from each other, close to the idealized $90^{\circ}$ for a regular octahedron. Angles generated at the nickel center by the chelating donor points $(\mathrm{N}$ and $\mathrm{S}$ ) differ slightly in the two coordinating ligands. It appears that the angles at the nickel center in the chelate rings are controlled to some extent by the ligand geometry. The bond distances and angles around the nickel atom are in agreement with the literature values. ${ }^{3-5}$ The angle between the mean planes of $\mathrm{Ni}, \mathrm{S} 2, \mathrm{~N} 7, \mathrm{~N} 8, \mathrm{C} 11$ and $\mathrm{Ni}, \mathrm{N} 8, \mathrm{~N} 9, \mathrm{C} 13, \mathrm{C} 14$ is $1.66(4)^{\circ}$ and that between mean planes of Ni, S1, N3, N4, C10 and Ni, $\mathrm{N} 2, \mathrm{~N} 3, \mathrm{C} 7, \mathrm{C} 8$ is $4.41(4)^{\circ}$, respectively.

The crystal data and the other relevant parameters are given in Table 1. The final atomic coordinates, the bond distances and angles are presented in Tables 2 and 3.

\section{Acknowledgements}

The authors wish to acknowledge the Faculty of Arts and Sciences, Ondokuz Mayis University, Turkey, for the use of the Stoe IPDS-2 diffractometer purchased under grant F.279 of the University Research Fund.

\section{References}

1. D. X. West, S. B. Padhye, P. B. Sonawane, and R. C. Chikate, Asian J. Chem. Rev., 1990, 1, 125.

2. E. C. Moore, M. S. Zedeck, K. C Agrawal, and A. C Sartorelli, Biochemistry, 1970, 9, 4492.

3. L. Thelander and A. Gräslund, J. Biol. Chem., 1983, 258, 4063.

4. W. Kaska, C. Carrano, J. Michalowski, J. Jackson, and W. Levinson, Bioinorg. Chem., 1978, 8, 225.

5. S. K. Chattopadhyay, D. T. Benerjee, R. Kuroda, and S. Ghosh, Polyhedron, 1997, 16, 1925. 